\title{
TACKLING EMPTY VOTING IN THE EU: THE SHARE- HOLDERS' RIGHTS DIRECTIVE AND THE REVISED TRANSPARENCY DIRECTIVE *
}

\author{
Edita Čulinović-Herc** and Antonija Zubović ${ }^{* * *}$
}

\begin{abstract}
Summary: The rise of the capital market creates new, less noticeable forms of holdings of shares. These holdings could be acquired with the aim of influencing a company's decision-making process without the intention to hold shares for the long term. One of the forms is new vote buying which can appear either as empty voting or as hidden ownership. Empty voting refers to voting by a shareholder without the corresponding financial interest in the company involved. The reverse situation is hidden ownership whereby a party is not the shareholder but is entitled to exercise influence and eventually vote as if he/she were a shareholder. If a shareholder has an ownership interest in the company in which he/she votes, his/her voting would be aligned with the interests of the company. If a shareholder votes for a decision contrary to the company's interest, it would affect his/her own economic interests because the shares could have been sold even before the shareholder's meeting occurred.
\end{abstract}

There are many techniques that lead to empty voting. Those most commonly used are: borrowing shares, using equity swaps or buying shares on a date close to the record date and then selling them again right after the record date has elapsed. As a result, a person casting their vote at the general meeting might not be the 'actual' shareholder. The admissibility of these votes and their effects have been discussed in well-known judicial cases.

Having noticed a rise of abusive situations created by using empty voting techniques at the EU level, the revised Transparency Directive set out to deal with these issues. It entered into force on 26 November 2013 with the deadline for implementation set at 26 November 2015. However, since the Transparency Directive is a minimum harmoni-

\footnotetext{
This paper has been supported in part by the Croatian Science Foundation project no 9366 'Legal Aspects of Corporate Acquisitions and Knowledge Driven Companies' Restructuring' and in part by the University of Rijeka project no 13.08.1.2.01 'Protection of Beneficiary on the Croatian and European Financial Services Market'.

** Edita Čulinović-Herc, PhD, Full Professor, Department of Commercial Law and Company Law, Faculty of Law, University of Rijeka.

*** Antonija Zubović, PhD, Senior Assistant in the Department of Commercial Law and Company Law, Faculty of Law, University of Rijeka.
} 
sation Directive, Member States have substantial liberty in its implementation which might lead to a divergent level of investor protection. Further, since the development of capital markets leads to the appearance of new forms of derivatives and other financial instruments which could create an 'empty voting' effect, EU Member States would be tempted to set rules that would, as far as possible, embrace all forms of empty voting in a so-called 'catch all' provision.

This paper aims to examine how national legislators of the EU Member States have dealt with the issue of empty voting in light of the solutions provided in the Shareholders Rights Directive of 2007 and in the revised EU Transparency Directive of 2013.

\section{Introduction}

One of the fundamental principles of company law is the principle of the indivisibility of a share. ${ }^{1}$ This means that voting rights ('control rights') and economic interests ('economic rights' or 'ownership rights') are intrinsically bound up in a single share. However, there are different strategies of decoupling the voting rights from cash flow rights, which is contrary to the principle of the indivisibility of the share. ${ }^{2}$ The importance of voting rights attached to shares is significant. When exercising voting rights, a shareholder directly takes part in the decision-making process and thereby indirectly influences the market value of the company's shares.

It is well known that institutional investors, hedge funds, ${ }^{3}$ and banks simultaneously hold the shares of various (listed) companies. The more votes they hold, the more influence they have at the general meeting. Building up their voting share portfolio could be done in various ways. Since the quantity of their holdings in shares affects their exposure to the (investment) risk, they prefer to avoid risk exposure whenever possible. It is a widely known practice that they can avoid their shareholder

\footnotetext{
1 The principle of the indivisibility of a share is explicitly prescribed in Art 163(7) of the Croatian Companies Act, Official Gazette of the Republic of Croatia, No 111/93, 34/99, $52 / 00,118 / 03,107 / 07,146 / 08,137 / 09,125 / 11,152 / 11,111 / 12,68 / 13$. The same is prescribed in Art 8(5) of the German Stock Corporation Act (AktG), Art 8(5) of the Austrian Stock Corporation Act, Art L 228-5 of the French Commercial Code, Art 2347(1) of the Italian Civil Code and Art 66(1) of the Spanish Corporations Act.

2 K Schmidt and M Lutter, Aktiengesetz Kommentar (Verlag Dr Otto Schmidt 2008) 15491550 pointed out that the shareholders' right in a company cannot be separated from the voting right. U Hüffer, Aktiengesetz (1 $1^{\text {th }}$ edn, CH Beck 2014) 26-27.

3 As Ringe points out 'empty voting is a strategy, mostly used by activist hedge funds, to eliminate economic risk from share ownership'. WG Ringe, 'Empty Voting Revisited: The Telus Saga' (2013) Oxford Legal Studies Research Paper No $18<$ http://ssrn.com/abstract=2230528> accessed 23 April 2015.
} 
status even before a decision is rendered, leaving the investment risk to other shareholders. There are various techniques that enable shareholders to acquire voting control in a company, without exposing them to investment risk. A shareholder with reduced exposure to risk retains his/her voting power and his/her influence in the company, but does not bear the risk of negative returns. Ringe calls this strategy "negative decoupling'. There is also 'positive decoupling'. ${ }^{4}$ This happens when an institutional investor wants to acquire an economic interest in a company without gaining voting power. Hu and Black ${ }^{5}$ use the term 'empty voting' for 'negative decoupling' whereas the reverse situation is called 'hidden ownership'. ${ }^{6}$ Institutional investors such as hedge funds try to 'disconnect the relationship between equity and risk', ${ }^{7}$ and the modern capital market offers many techniques to achieve these goals.

Empty voting refers to voting by a shareholder without a corresponding financial interest in the company in which the shareholder votes. ${ }^{8}$ If a shareholder has an economic interest (investment risk) in the company in which he/she votes, his/her voting is aligned with the interests of the company. If such an interest is non-existent, so is the risk, and the person may vote freely as he/she pleases. The phrase empty voting derives from the idea that the shareholder's vote has been emptied of the economic consequences that he/she would typically face as a shareholder. ${ }^{9}$ The reverse situation is 'hidden ownership' (or 'positive decoupling') where a party is not the shareholder but is entitled to exercise influence and eventually votes as if he/she were a shareholder. In practice, the holder of the financial instrument becomes economically exposed to fluctuations in the price of the share, and may informally bring his/her influence to bear on whoever holds the voting right. For this reason, the situation in question is also defined as 'a combination of a non-disclosed

\footnotetext{
4 WG Ringe, 'Hedge Funds and Risk-Decoupling: The Empty Voting Problem in the European Union' (2012) Oxford Legal Studies Research Paper No 52 <http://ssrn.com/abstract $=2135489>$ accessed 20 April 2015.

5 H Hu and B Black, 'The New Vote Buying: Empty Voting and Hidden (Morphable) Ownership' (2006) 79 Southern California Law Review 811.

6 H Hu and B Black, 'Empty Voting and Hidden (Morphable) Ownership: Taxonomy, Implications, and Reforms' (2006) 61 The Business Lawyer 1011-1070; Hu and Black (n 5) 811-908; H Hu and B Black, 'Hedge Funds, Insiders, and Empty Voting: Decoupling of Economic and Voting Ownership in Public Companies' (2007) 15 Journal of Corporate Finance 343-367; H Hu and B Black 'Equity and Debt Decoupling and Empty Voting II: Importance and Extensions' (2008) 156 University of Pennsylvania Law Review 625-739.

7 Ringe (n 4) 2.

8 European Corporate Governance Forum, 'Statement on Empty Voting and Transparency of Shareholder Positions' (20 February 2010) $\square$ http://ec.europa.eu/internal_market/company/docs/ecgforum/ecgf_empty_voting_en.pdf $\square$ accessed 05 July 2014.

9 JM Barry, JW Hatfield and SD Kominers, 'On Derivatives Markets and Social Welfare: A Theory of Empty Voting and Hidden Ownership' Virginia Law Review (2013) 99(1103) <http://ssrn.com/abstract=2134458> accessed 03 July 2014.
} 
economic interest joined with a probable informal voting power. ${ }^{10}$ Generally, it is exercised by using financial derivatives, of which the equity swap is the most common example.

Empty voting has attracted the attention of the courts and academics during the past few years. The latest example is the Telus case involving a Canadian Telecommunications Company which became the target of the US hedge fund Mason Capital. The battle between Telus and Mason continued in the courtroom and resulted in two differing court rulings. ${ }^{11}$ The last one by the Supreme Court relied more on the rules which permit the court to assess the fairness of the proposed solutions. However, in the dispute brought (previously) to the Court of Appeal, the subject matter of the dispute was regulated by very firm rules, leaving the court with no room for a functional approach to the problem.

\section{Empty voting strategies}

The European Corporate Governance Forum (ECGF), in its Statement on Empty Voting and Transparency of Shareholder Positions of $2010,{ }^{12}$ pointed out many techniques allowing empty voting. In the doctrine, three main strategies are known: borrowing shares / share lending, use of financial derivatives, especially equity swaps, and record date capture, ie buying or lending shares on a date close to the registration date. Record date capture means that shares are traded in the period between the record and voting date, and then sold back right after the record date. This means that the person who votes at the general meeting does not need to be the 'actual' shareholder at the moment when the voting occurs.

\footnotetext{
10 European Commission, 'Impact assessment accompanying the document Proposal for a Directive of the European Parliament and of the Council amending Directive 2004/109/EC on the harmonisation of transparency requirements in relation to information about issuers whose securities are admitted to trading on a regulated market' - Commission staff working paper (25 October 2011) <http://www.europarl.europa.eu/registre/docs_autres_institutions/commission_europeenne/sec/2011/1279/COM_SEC(2011)1279_EN.pdf> accessed 10 July 2014; Hu and Black (n 5) 817; Hu and Black 'Empty Voting and Hidden (Morphable) Ownership' (n 6) 1014; H Fleischer and KU Schmolke, 'Zum beabsichtigten Ausbau der kapitalmarktrechtlichen Beteiligungstransparenz bei modernen Finanzinstrumenten ( $\S \S 25$, 25a DiskE-WpHG)' (2010) 22 Neue Zeitschrift für Gesellschaftsrecht 847.

11 In TELUS Corporation v Mason Capital Management LLC 2012 BCCA 403, the Court of Appeal for British Colombia held that Mason's risk exposure and its potential status as 'empty voter' did not allow the first instance court to disregard the valid calling of the meeting. The court held that it is '...not in a position to take into account the risk exposure for purposes of assessing whether Mason was allowed to call a meeting'. In a different vein, the Supreme Court of British Columbia, in Re TELUS Corporation, 2012 BCSC 1919, approved the plan of arrangement as proposed by Telus. It ruled that the 'empty voting' situation was indeed one of the factors that had to be taken into account for assessing whether the proposed arrangement (conversion) would be fair for all shareholders, including the hedge fund Telus. See Ringe (n 3) 2.

12 European Corporate Governance Forum (n 8).
} 


\subsection{Use of financial derivatives to reduce or eliminate investment risk}

The financial industry has developed a number of instruments that reduce or even eliminate exposure to shareholder investment risk and shift the risk to another market participant. Equity swap derivatives are suitable to transfer the entire risk of share price movements to the market participant, often called short party. An equity swap can be settled in equity or in cash. The latter is known as cash-settled derivatives (hereinafter: CSDs). According to Conac, ${ }^{13}$ the CSD is a financial contract between an investor (long party) and an investment bank (short party), transferring the investment risk to the short party. If the price of the share rises, on the date of the termination of the contract the investor (shareholder) receives the difference between the price of the share at the time the contract was entered into and the price of the share at the end of the contract, as well as any dividend paid by the company. In exchange, the investor is to pay a fee, as well as the corresponding interest for the contract, and to compensate the short party if the price of the share has fallen below the price set at the beginning of the contract. CSDs, besides equity swaps, ${ }^{14}$ may take many forms: as options, ${ }^{15}$ contracts for difference, etc. In a typical cash-settled equity swap, the long equity side ('the equity leg') acquires economic interest in the shares (but not voting rights) from the short side ('the interest leg'). The combined position (long shares, short equity swaps) conveys voting rights without financial interest. Conversely, a long equity swap position conveys financial interest without 'formal' voting rights. Since the swap is the future contract, at the moment the swap matures its settlement is possible in cash (cash

\footnotetext{
13 PH Conac, 'Cash-Settled Derivatives as a Takeover Instrument and the Reform of the EU Transparency Directive' in HS Birkmose, M Neville and KE Sørensen (eds), The European Financial Market in Transition (Kluwer Law International 2012); ES de Nardis and M Tonello, 'Know Your Shareholders: The Use of Cash-Settled Equity Derivatives to Hide Corporate Ownership Interests' (2010) Conference Board Director Notes No DN-009 <http://ssrn. com/abstract=1648526> accessed 11 July 2014; M Sauter, 'Anschleischen an Übernahmeziele mit Hilfe von Aktienderivaten' in T Baums, Governance und Anlegerschutz (Mohr Siebeck 2013) 588; S James, The Law of Derivatives (LLP Publishing 1999) 8.

14 The most common forms of swaps are interest rate swaps and currency swaps. See more in F Caputo Nassetti, I contratti derivati finanziari ( $2^{\text {nd }}$ edn, Giuffrè Editore 2011) 23; S Das, Swaps and Financial Derivatives ( $2^{\text {nd }}$ edn, The Law Book Company Limited 1994) 52-79; SK Henderson, Henderson on Derivatives (Elsevier 2003) 33. From the point of view of Croatian law, see Z Slakoper and M Beroš Božina, 'Ugovor o valutnom i kamatnom swapu' (2009) 30(2) Zbornik Pravnog fakulteta Sveučilišta u Rijeci 944-985. On total return swaps (TRS) and their role in takeovers, see D Stanković, 'Use of Cash-Settled Derivatives in Public Takeovers: A Challenge for Legislators, Regulators and Courts' (2012) <http://ssrn.com/ abstract=2290899> accessed 11 July 2014; D Christ, Barausgleichsderivate und das Anschleichen an Zielgesellschaften (Nomos 2011) 46-49.

15 Options are derivatives entitling the long party to either buy (call options) or sell (put options) the underlying asset in the future. F Bolliger, 'Wettartige Finanzprodukte - wo ist die Grenze?, Zum Differenzeinwand im Anlagegeschäft' in LD Loacker and C ZellwegerGutkneckt (eds), Differenzierung als Legitimationsfrage (Dike Verlag AG 2012) 217-221.
} 
settled) or in shares (equity settled), depending on the style of the swap. If the investor settles 'physically' ie in shares, he/she may, at once, acquire a block of voting rights large enough to gain control, without necessarily being a shareholder prior to the settlement or without being a shareholder in a minor percentage. Ringe ${ }^{16}$ points out how a similar result can be achieved by applying option contracts. The shareholder may use a short call (ie the sale of a right to purchase) or a long put (ie the purchase of a right to sell), or even simply apply short selling.

An equity swap was applied as an empty voting strategy in the famous Mylan / Perry case when Mylan and Perry were struggling over a target - King Pharmaceuticals. In that case, the hedge fund Perry Corp owned a large position in King Pharmaceuticals. ${ }^{17}$ On 26 July 2004 Mylan Laboratories announced an agreement to acquire shares of King Pharmaceuticals through a stock-for-stock merger at a significant premium over King's trading price. ${ }^{18}$ While being a significant shareholder in King, Perry wanted to benefit from the acquisition. Since it was unclear whether the merger would be beneficial for Mylan, ${ }^{19}$ when the deal was announced King shares rose but Mylan shares dropped. While the proposed acquisition was subject to the approval of both Mylan's and King's general meeting, Perry began an unusual strategy - they acquired 9.9\% of Mylan shares ${ }^{20}$ to help Mylan receive the shareholders' approval for the merger. ${ }^{21}$ In order to remove any risk of a drop in the Mylan share price, Perry Corp entered into total return equity swaps with third parties, and as a result was able to vote in favour of the merger without fearing any potential economic risk as the holder of Mylan shares. ${ }^{22}$

\footnotetext{
16 Ringe (n 4) 7.

17 See more in Hu and Black, 'Empty Voting and Hidden (Morphable) Ownership' (n 6) 1015; D Yermack, 'Shareholder Voting and Corporate Governance' (2010) <http://papers. ssrn.com/sol3/papers.cfm?abstract_id=1523562> accessed 03 July 2014; I Theusinger and D Möritz, 'Empty Voting als moderner Stimmenkauf?' (2010) 16 Neue Zeitschrift für Gesellschaftsrecht 607; M Wright, DS Siegel, K Keasey and I Filatotchev (eds), The Oxford Handbook of Corporate Governance (OUP 2013) 577.

18 The proposed transaction provided that King shareholders would receive 0.9 shares of Mylan common stock for each outstanding share of King stock, which represented a $61 \%$ premium for King shareholders as of the date of the announcement.

19 Mylan shareholders, including activist Carl Icahn, publicised their intention to vote against their firm's proposed acquisition.

20 A second hedge fund, Citadel, acquired another $4.4 \%$ of Mylan shares and was rumoured to have followed a strategy similar to Perry. See more in Hu and Black, 'Empty Voting and Hidden (Morphable) Ownership' (n 6) 1024-1025.

21 Since the Perry Corp hedge fund did not have any economic risk in Mylan shares, it intended to vote in favour of the transaction, even though such a vote would likely have helped drive the Mylan share price down. Moreover, the more Mylan (over)paid for King Pharmaceuticals shares, the more the Perry Corp hedge fund would profit. However, Mylan abandoned the acquisition because of accounting problems at King.

22 It is also necessary to point out that the Perry Corp hedge fund did not notify on acquiring shares and therefore violated regulations in Section 13(d) SEA of 1934, ie Rule 13d-1
} 


\subsection{Share lending / borrowing}

According to Ringe,

the notion of 'share lending' is slightly misleading, because it describes a transaction where securities are not just 'lent' and then re-transferred, but rather, one party transfers the ownership of numerous securities to another, and at a later time, is returned a corresponding number of shares. ${ }^{23}$

Technically speaking, this strategy resembles more a repurchase agreement than simple borrowing. When borrowing is in question, the title remains with the lender. The same author points out that it is crucial to understand that the legal structure necessarily implies a transfer of ownership between the lender and the borrower, and that the borrower also acquires the voting right attached to the share. ${ }^{24}$ As long as the borrower does not return the shares to the lender, the lender 'keeps' the beneficial ownership rights in the company while the borrower acquires temporary control. ${ }^{25}$ From the company's viewpoint, the borrower is considered a shareholder whereas the lender and the borrower agree upon the duration of the agreement, the dividend pay-out, and other relevant aspects in the contract. ${ }^{26}$ The fact that the borrower of the share acquires the voting right, whereas the economic benefits, in accordance with the contract, are transferred to the lender of the share, leads to empty voting - ie the misalignment of voting rights and respective economic benefits compared to the total number of shares one person holds. ${ }^{27}$ The borrower may acquire shares solely with the aim of gaining the voting right at the general meeting, and then returning the lent shares back to the lender. ${ }^{28}$

and had to pay a fine of $\$ 150,000$. For more on this case, see US Securities and Exchange Commission, 'SEC Charges Perry Corp with Disclosure Violations in Vote Buying Scheme' (press release, 21 July 2009) at $\square$ http://www.sec.gov/news/press/2009/2009-165.htm $\square$ accessed 07 July 2014.

23 Ringe (n 4) 9.

24 M Mittermeyer, Empty Voting - Risikoentleerte Stimmrechtsausübung im Recht der börsennotierten Aktiengesellschaft (Walter De Gruyter 2014) 8.

25 See more in A Baumbach and KJ Hopt, Handelsgesetzbuch (36th edn, CH Beck 2014) T/1-T/3; A Zubović, 'Stjecanje glasačke kontrole nad uvrštenim društvom' (Doctoral dissertation, University of Zagreb 2012) 322-329; H Schimansky, HJ Bunte, HJ Lwowski, Bankrechts-Handbuch (4th edn, CH Beck 2011) Rn 3.

26 Mittermeyer (n 24) 101.

27 An increased volume of stock lending around annual meeting record dates has been noticed. This is particularly evident in the UK. Furthermore, research conducted in the USA points to a high percentage of share borrowing - up to $20 \%$ of an individual company's shares. See Hu and Black, 'Empty Voting and Hidden (Morphable) Ownership' (n 6) 1028.

28 The loan is typically callable at any time by the lender and repayable at any time by the borrower. R Aggarwal, PAC Saffi and J Sturgess, 'Does Proxy Voting Affect the Supply and/ or Demand for Securities Lending?' (2011) < http://www2.lebow.drexel.edu/PDF/Docs/ 
There are many collateral issues in respect of share borrowing / lending. Regarding the admissibility of voting on the basis of borrowed shares, there are some contrasting views. While OECD does not hold this to be an issue, ${ }^{29}$ the Securities Lending and Repo Committee is of the opinion that 'lenders should also consider their corporate governance responsibilities before lending stock over a period in which an AGM or EGM is expected to be held'. ${ }^{30}$

Another aspect, whether the borrower is obliged to vote according to the lender's instructions, is addressed by the Global Master Securities Lending Agreement (hereinafter: GMSLA), designed by the International Stock Lending Association (hereinafter: ISLA). ${ }^{31}$ The borrower is generally not obliged to vote according to the lender's instructions, but this could be agreed upon differently. ${ }^{32}$ However, even if the borrower votes contrary to the lender's instructions, such voting is considered valid visà-vis the company and as such does not affect the validity of the decision rendered on the basis of that vote. If the shares are held by the company itself (also known as treasured shares), the question is whether they are suitable for lending. Article 22(1) of the Second Company Law Directive ${ }^{33}$ provides that the shares held by the issuing company itself are exempted from voting for the whole period during which the shares are treasured shares. Companies might have good reason to lend treasured shares in order to obtain certain revenue. While the general view is that the bor-

CorpGov/2011Conf/AGGARWAL_Saffi_Sturgess_Proxy_Voting_and_Securities_Lending. pdf $>$ accessed 21 July 2014, emphasize an increased demand for borrowing shares around the time of the record date.

29 OECD Steering Group on Corporate Governance, "The Role of Private Pools of Capital in Corporate Governance: Summary and Main Findings about the Role of Private Equity Firms and 'Activist' Hedge Funds' (May 2007) $\square$ http://www.oecd.org/corporate/ca/corporategovernanceprinciples/38672168.pdf $\square$ accessed 27 April 2015.

30 Securities Lending and Repo Committee, 'Securities Borrowing and Lending Code of Guidance' (December 2004) $\square$ http:/ /www.bankofengland.co.uk/markets/pages/gilts/slrc. aspx $\square$ accessed 04 July 2014. See also International Securities Lending Association, 'Securities Lending \& Corporate Governance’ (December 2000) $\square$ http://www.lseg.com/sites / default/files/content/documents/securities-cg.pdf $\square$ accessed 13 April 2015.

31 International Stock Lending Association, 'Global Master Securities Lending Agreement' (2010)<http://www.isla.co.uk/wp-content/uploads/2015/08/GMSLA_2010_amendments_July_2012-1.pdf $\square$ accessed 22 November 2015.

32 According to the Securities Borrowing and Lending Code of Guidance applied in the UK, the lender and the borrower define terms of acquiring voting right at the general meeting in the signed agreement. See further in P Santella and others, 'Comparative Analysis of the Legal Obstacles to Institutional Investor Activism in the EU and in the US' (2009) $\square$ http:// ssrn.com/abstract $=1137491 \square$ accessed 14 July 2014, published also in (2012) 23 European Business Law Review.

33 Council Directive (EEC) 77/91 on coordination of safeguards which, for the protection of the interests of members and others, are required by Member States of companies within the meaning of the second paragraph of Article 58 of the Treaty, in respect of the formation of public limited liability companies and the maintenance and alteration of their capital, with a view to making such safeguards equivalent [1977] OJ L26/1. 
rower acquires full legal title to the shares (although on a temporary basis), the company lending the treasured shares might thereby activate (otherwise) blocked voting rights. As the decision to lend the treasured shares is taken by the board of directors, the board might decide to lend them in order to influence the outcome of a general meeting. ${ }^{34}$ Instead of prohibiting all forms of lending of treasured shares, the ECGF recommends ${ }^{35}$ the adoption of a rule that the company and its subsidiaries may lend the company's own shares only if the lending agreement stipulates that the borrower will not vote with these shares, and could ensure that third parties acquiring the title in the (borrowed) shares will not vote either. The company should disclose prior to the general meeting to what extent it and its subsidiaries have lent the company's own shares to third parties.

Borrowed shares were used as an instrument for empty voting in the Lindner case, decided before the German Federal Supreme Court in $2009,{ }^{36}$ where, through a securities lending agreement, the shares of the partnership company limited by shares were lent to a limited partner, who thereby acquired a stake exceeding 95\% in the share capital and demanded the initiation of a squeeze-out procedure. The German Supreme Court was of the opinion that a squeeze out based on securities lending does not amount to abusive practice, while a lending agreement should not give the borrower 'share ownership of a second class', but full ownership of the 'borrowed' shares. Another example is the Laxey Partners / British Land case. Shortly before the general meeting of British Land in 2002, the hedge fund Laxey Partners ${ }^{37}$ (UK) announced that they had tripled their equity stake in it (from 2.9 to 9\%). Laxey Partners did not support the re-election of the British Land chairman. Even though Laxey's proposals did not succeed, ${ }^{38}$ the case showed voting manipulation through borrowed shares. It was questionable whether the Laxey Partners Fund had any other hidden interests connected with British

\footnotetext{
34 See more in E Wymeersch, 'Shareholder(s) Matter(s)' in Festschrift für Klaus J Hopt: Unternehmen, Markt und Verantwortung (Walter De Gruyter 2010) 1573, 1575.

35 Commission (EC), "The review of the operation of Directive 2004/109/EC: Emerging issues. Accompanying document to the Report from the Commission to the Council, the European Parliament, the European Economic and Social Committee and the Committee of the Regions Operation of Directive 2004/109/EC on the harmonisation of transparency requirements in relation to information about issuers whose securities are admitted to trading on a regulated market' COM (2010) 243, 27 May $2010<$ http://ec.europa.eu/ internal_market/securities/docs/transparency/directive/sec-2010_611_en.pdf> accessed 7 April 2015.

36 Bundesgerichtshof (German Supreme Court), judgment of 16 March 2009 (II ZR 302/06), BGHZ 180, 154.

37 The Laxey Partners Hedge Fund is a subsidiary company to Laxey Partners Ltd.

38 The three institutions that lent out shares, Hermes, Barclays Global Investors, and Scottish Widows, apologised to British Land.
} 
Land shares, especially relating to the share market price in a way that would generate additional profit for them by means of a share refund. ${ }^{39}$

On a more practical level, it should be emphasised that share lending is available at low cost (although high security payments are to be made to the lender who is not willing to bear the default risk of the borrower). ${ }^{40}$ Because of various incentives given to the lenders, only a tiny fraction of all share loans are recalled (not more than $2 \%$ of all lent shares). ${ }^{41}$

\subsection{Trading / borrowing shares in the period between the record date and the voting date (record date capture)}

When shares are traded (or borrowed) in the period between the record date and voting date, this may lead to empty voting.

The record date is the cut-off date for registering for the general meeting. Since the record date is generally not set at the date of the general meeting (but some time before), this allows voters (registered shareholders) to sell shares before the general meeting but to vote as if they were regular shareholders. According to the record date method, shareholders are solely persons who hold shares on the day the general meeting is held or within a specific timeframe before the general meeting is called. The other method is reconciliation ${ }^{42}$ - putting share transactions on hold, but that method does not encourage shareholders to exercise their voting rights at all. ${ }^{43}$

When applying the record date system, a specific date before the shareholder's meeting is set in advance as the date (often close to the voting date) on which the person who intends to vote at the general meeting must be identified as a shareholder. ${ }^{44}$ After the shareholders' registra-

\footnotetext{
39 Mittermeyer (n 24) 8.

40 Ringe (n 4) 13.

41 G D'Avolio, 'The Market for Borrowing Stock' (2002) 66 Journal of Financial Economics 271.

42 A reconciliation requires the shareholder to hold (or even to deposit) the shares for a day or within a timeframe of 24 to 48 hours before voting occurs. The shareholder would deposit shares in a certain institution for a pre-set period of time before the voting. If nonmaterialised securities are involved, authorised institutions issue a certificate stating that the shares held on their accounts have been blocked, about which they inform the joint stock companies.

43 D Jurić, 'Pravno uređenje unutarnjeg korporacijskog upravljanja (corporate governance) u dioničkim društvima u hrvatskom i usporednom pravu društava' (Doctoral dissertation, University of Rijeka 2005) 135; U Noack and DA Zetzsche, 'Corporate Governance Reform in Germany: The Second Decade' (2005) 16 European Business Law Review 1043.

44 In EU (as well as in US) law, the right to vote at a general meeting is tied to the shares held by shareholder on a specified date prior to the general meeting (the record date). European Parliament and Council Directive (EC) 2007/36 on the exercise of certain rights of shareholders in listed companies [2007] OJ L184/17, Art 7 para 2; Latham\&Watkins, "Empty Voting" and Other Fault Lines Undermining Shareholder Democracy: The New
} 
tion, share transactions might freely continue. Once the registered shareholders have been identified, they remain entitled to vote notwithstanding the fact that they have meanwhile alienated their shares. When the record date is set very close to the date of the general meeting, investors who have alienated a (significant) block of shares/votes upon their registration would not notify the market about their disinvestment, which they should normally do within the course of a few working days. Therefore, capital market participants could be led to believe they were actual shareholders. ${ }^{45}$

\section{Empty voting and the Shareholders Rights Directive}

The requirements for participation and voting in a general meeting are prescribed in Article 7 of the Shareholders Rights Directive (hereinafter: SRD). ${ }^{46}$

Article $7(2)$ SRD adopted the record date system. The record date must not lie more than 30 days before the date of the general meeting to which it applies, and at least eight days must elapse between the latest permissible date for the convocation of the general meeting and the record date. ${ }^{47}$ Therefore, the voting right might be exercised by a person who is the holder of the share on a specific date prior to the general meeting - ie the record date. ${ }^{48}$ The provisions of the SRD eliminate the possibility of making the storing of shares prior to the meeting or the setting of transactions on hold (reconciliation) a condition for participating in the general meeting and for the admissibility to vote. ${ }^{49}$ This method is

Hunting Ground for Hedge Funds' (M\&A Deal Commentary) (2007) <http://www.lw.com/ upload/pubContent/_pdf/pub1878_1.Commentary.Empty.Voting.pdf> accessed 15 July 2014; A Brav and RD Mathews, 'Empty Voting and the Efficiency of Corporate Governance' (2010) AFA 2009 San Francisco Meetings Paper <http://ssrn.com/abstract=1108632> accessed 15 July 2014; ND Luca, 'Titolarità vs legittimazione: a proposito di record date, empty voting e "proprietà nascosta" di azioni' (2010) 2 Rivista di diritto societario 311-339.

45 On the importance of transparency rules in similar cases, see more in Commission (EC) (n 35) 15.

46 European Parliament and Council Directive (EC) 2007/36 on the exercise of certain rights of shareholders in listed companies [2007] OJ L184/17.

47 In calculating that number of days, those two dates shall not be included. The NYSE Listed Company Manual suggests a minimum of 30 days should elapse between the record date and voting date. NYSE Listed Company Manual (2009) <http: / / nysemanual.nyse. com/lcm/> accessed 20 July 2014.

48 Shareholders Rights Directive 2007/36 Art 7(2).

49 The Shareholders Rights Directive 2007/36 Art 7(1) imposes an obligation on Member States to ensure that the rights of a shareholder to participate in a general meeting and to vote in respect of any of his/her shares are not subject to any requirement that his/her shares be deposited with, or transferred to, or registered in the name of another natural or legal person before the general meeting and that the rights of a shareholder to sell or otherwise transfer his/her shares during the period between the record date and the general meeting to which it applies are not subject to any restriction to which they are not subject at other times. 
particularly inconvenient for institutional investors. Practice shows that institutional investors have abstained many times from voting if it was mandatory for them to block or to deposit shares. The liquidity risk is real since share blockage could be extended if the general meeting is not held at the first call. ${ }^{50}$

According to the adopted provisions, disclosure of information on voting rights before the general meeting does not prevent empty voting. ${ }^{51}$ However, the shorter the period of time between the record date and the voting date, the less likely is it for empty voting to occur. ${ }^{52}$

When companies are able to identify the names and addresses of their shareholders from the current register of shareholders on the day of the general meeting, Member States may depart from the record date rule. ${ }^{53}$

Pursuant to the provision of Article 7(3) SRD, Member States must ensure that a single record date applies to all companies. ${ }^{54}$ However, Member States may set one record date for companies which have issued bearer shares and another record date for companies which have issued registered shares, provided that a single record date applies to each company which has issued both types of shares.

Article 15 SRD imposes the obligation on Member States to communicate to the Commission the number of days set as the record date. ${ }^{55}$ In order to encourage shareholders to vote, Member States are obliged to ensure that the proof of capacity of a shareholder is made subject only to such requirements that are necessary to ensure the identification of the shareholders and only to the extent that is proportionate for achieving that objective (Article 7(3) SRD).

Croatia and Germany share a great deal in regulating the question of the record date. In Croatia (Article 279(2) of the Croatian Companies

\footnotetext{
50 See more in E Čulinović Herc and D Jurić, 'Prekogranični aspekti prava glasa - otvorena pitanja u europskom i hrvatskom pravu' (2006) Zbornik radova s međunarodnog znanstvenog skupa Prekogranična i regionalna suradnja 221.

51 Brav and Mathews (n 44) 7 point out that it should publish information on share trading between the record date and voting date.

52 PL Davies, S Worthington and E Micheler, Gower and Davies' Principles of Modern Company Law, (8th edn, Sweet \& Maxwell 2008) 465; PE Masouros, 'Is the EU Taking Shareholder Rights Seriously? An Essay on the Impotence of Shareholdership in Corporate Europe' (2010) 7(5) European Company Law 198.

53 Luca (n 44) 318.

54 U Noack, 'The Shareholder Rights Directive (Die Aktionaersrechte-Richtlinie)' (2008) Festschrift für H. P. Westermann, CBC-RPS No 0034 <http://ssrn.com/abstract=1138735> accessed 06 July 2014.

55 European Commission (EC) List of days provided for according to Article 15 of Directive 2007/36/EC [2010] OJ C285/1.
} 
Act) and in Germany (Article 123(2) AktG), ${ }^{56}$ a joint-stock company in its articles of incorporation may require a shareholder to apply for the general meeting in order to be able to participate and/or vote in it. ${ }^{57}$ The application form should reach the company at the latest six days prior to the general meeting if a shorter closing date is not otherwise provided for in the articles of incorporation. ${ }^{58}$ If identification of the shareholder is required, the deadline for the convocation of a general meeting (at least a month prior to the date of the general meeting) is extended by the length of the registration (identification) period. ${ }^{59}$ As for the manner of the shareholder's identification, ${ }^{60}$ both German and Croatian law differentiate between the identification of the holders of bearer shares and that of the holders of registered shares. While the first would identify themselves in the manner prescribed in the company's articles of incorporation, the shareholders of listed companies should provide evidence in writing issued by the depositary institution where the accounts of registered shares are held. ${ }^{61}$ In the case of listed companies, the evidence must refer to the beginning of the $21^{\text {st }}$ day prior to the date of the general meeting. It must be received by the company at least six days prior to the general meeting if a shorter deadline is not otherwise prescribed in the articles of incorporation. ${ }^{62}$ This deadline cannot be extended by the company because this would cause shareholders difficulties in exercising their right to participate in the general meeting. ${ }^{63}$ Only a person who submits the

56 Croatian Companies Act (n 1) Art 279(2). The provisions of Art 123 AktG were amended in 2005 and 2009. See Gesetz für Unternehmensintegrität und Modernisierung des Anfechtungsrecht (UMAG) published on 22 September 2005 (BGBl vol I, 802) and Gesetz zur Umsetzung der Aktionärsrechterichtlinie (ARUG) published on 30 July 2009 (BGBl vol I, 2479). For German law, see more in KV Nussbaum, 'Zu Nachweisstichtag (record date) und Eintragungssperre bei Namensaktien' (2009) 12 Neue Zeitschrift für Gesellschaftsrecht 456-58; MKF Henning, Das Recht der Aktionärsversammlung in Großbritannien und Deutschland (Nomos 2006) 174-181.

57 The convocation of the general meeting must include the conditions to be met in order to take part in the general meeting and to exercise the right to vote.

58 The date when the company receives the application is not calculated in the deadline.

59 E Čulinović Herc and T Hasić, 'Sudjelovanje dioničara u radu glavne skupštine dioničkog društva prema noveli Zakona o trgovačkim društvima' (2011) 32(1) Zbornik Pravnog fakulteta u Rijeci 47. The authors consider that the regulation was introduced in order not to shorten the month-long period shareholders usually have to decide on their participation in the general meeting.

60 Croatian Companies Act (n 1) Art 279(3) and Art 123(3) AktG.

61 In Croatia, this would be the Central Depository and Clearing Company, while in Germany written proof is issued by the Depotführende Institut. These are credit institutions (Kreditinstitute) or financial services institutions (Finanzdienstleistungsinstitute). W Hölters, $A k$ tiengesetz Kommentar ( $2^{\text {nd }}$ edn, CH Beck 2014) Rn 11; U Hüffer, Aktiengesetz $\left(11^{\text {th }}\right.$ edn, $\mathrm{CH}$ Beck 2014) Rn 11.

62 Croatian Companies Act (n 1) Art 279(3) and Art 123(3) AktG. The date when the company receives the application is not calculated in the deadline.

$63 \mathrm{~J}$ Barbić and others, Novela Zakona o trgovačkim društvima iz 2007 (Novi informator 2008) 39-40; J Barbić, 'Sazivanje glavne skupštine i ostvarivanje prava dioničara nakon novele Zakona o trgovačkim društvima iz 2009' (2010) Zbornik 48 susreta pravnika 13; F Ochmann, Die Aktionärsrechte-Richtlinie (De Gruyter Recht 2009) 104. 
prescribed proof is entitled to participate in the meeting and to vote. ${ }^{64}$ Therefore, according to Croatian and German law, the mandatory record date is at the beginning of the $21^{\text {st }}$ day prior to the general meeting (but only for holders of bearer shares).

The introduction of the record date system and abandonment of the share blocking system for all French listed companies ${ }^{65}$ is regulated by a Decree of 11 December 2006. ${ }^{66}$ Article R 225-85 of the French Commercial Code defines the record date as three working days prior to the general meeting. ${ }^{67}$ Shareholders who have already voted via mail or have appointed a proxy holder may sell their shares. However, if the process of selling shares continues in a period less than three days prior to the general meeting, the company must consider any such vote or proxy notice null and void (Fr. invalide ou modifie), and in the case of bearer shares, the broker or bank must disclose sales information to the company or person in charge of the registry. If the sale is completed within three days prior to the general meeting, there is no obligation for such information disclosure. Article L 225-104 of the Commercial Code prescribes that the manner and deadlines for convening general meetings are determined in a Council of State decree (Décret en Conseil d'Etat). However, members of the general meeting, management and supervisory board, and permanent legal entity appointed representatives (Fr. le président, les directeurs généraux, les membres du directoire d'une société, les personnes physiques ou morales exerçant dans cette société les fonctions d'administrateur ou de membre du conseil de surveillance ainsi que les représentants permanents des personnes morales qui exercent ces fonctions) are obliged by the above-mentioned decree to register, ie to store their shares or shares belonging to their spouses and minor children, issued by the company, its subsidiaries and controlling companies, if the shares in question are listed in the regulated securities market. ${ }^{68}$

\footnotetext{
64 According to the Croatian Companies Act (n 1) Art 277(4), the board, ie executive directors, and if the general meeting is called by the supervisory or management board, the notice calling the meeting, issued by the listed company board, must include the conditions to be met in order to partake in the general meeting and exercise the right to vote, as up to the day prescribed evidence under Art 279(3) of the Companies Act is to be submitted. The regulation in question is prescribed in German law under Art 121(3) AktG.

65 Prior to the implementation of the Shareholder Rights Directive in French law, the statute was allowed to prescribe the obligation to deposit shares five days prior to the general meeting as a means to impose a condition for participation and voting in the general meeting. See more in J Buhart and N Lafont in A Kawamura, A Mori \& Tomotsune (eds), Corporate Governance, Jurisdictional Comparisons ( $1^{\text {st }}$ edn, Sweet \& Maxwell 2013) 84.

66 Décret No 2006-1566 du 11 décembre 2006 modifiant le Décret No 67-236 du 23 mars 1967 sur les sociétés commerciales [2006] JORF 18762.

67 Art R 225-285 of the French Commercial Code amended by Art 4 of the Décret No 20092295 du 16 mars 2009.

68 Art L 225-109 of the French Commercial Code.
} 
In the UK, the SRD was implemented by the Companies (Shareholder Rights) Regulations. ${ }^{69}$ These amendments came into force on 3 August 2009. In UK law, publicly traded companies must determine the right to exercise voting rights at the meeting by reference to the register of securities at the time specified by the company and not more than 48 hours prior to the time set for the meeting. ${ }^{70}$ In practice, the vast majority of issuers choose the date as late as 18 hours before the general meeting. In calculating this period, only working days are counted. Changes of entries in the register of securities carried out after the time specified by the company are disregarded in determining the rights of any person to attend or vote at the meeting, notwithstanding any provisions in any enactment, articles of incorporation or other instrument to the contrary. However, the company in its articles of incorporation might make the right to attend the general meeting conditional upon the duty to register and store the shares. However, such a clause should be null and void if it limits the shareholder's right to attend and vote at the general meeting by prescribing the obligation to store or transfer shares or register them under another's person's name, or prevents the share transfer within a period of 48 hours prior to the general meeting. ${ }^{71}$

In Italy, the SRD was implemented by Legislative Decree No 27 of 27 January 2010. ${ }^{72}$ Article 2370(2) of the Italian Civil Code provides the right of the company to regulate the exercising of voting rights in its articles of incorporation. Companies whose shares are not admitted to the central depository (società le cui azioni non sono ammesse alla gestione accentrata) may require the shares to be deposited in advance (il preventivo deposito) at its registered office or in the banks indicated in the call for the general meeting. For companies whose shares, though not admitted to trading, are widely distributed among the public (diffuse fra il pubblico in

\footnotetext{
69 On 24 October 2008 the UK Department for Business, Enterprise and Regulatory Reform (BERR) published a document on consultation regarding the directive containing the UK Draft Regulations. After the completion of consultations, BERR drew up a final version of the Draft Regulations of 2 February 2009, SI 2009/1632, submitted to the Parliament on 3 February 2009, altering the provisions of the Companies Act 2006.

70 Reg 41(1) of the Uncertificated Securities Regulations 2001, SI 2001/3755.

71 See more in B Hannigan and others (eds), Hannigan and Prentice: The Companies Act 2006 - A Commentary (LexisNexis Butterworths 2009) 175-176; Davies, Worthington and Micheler (n 52) 490.

72 Legislative Decree No 27 of 27 January 2010, Attuazione della direttiva 2007/36/CE, relativa all'esercizio di alcuni diritti degli azionisti di societa' quotate, published in Official Gazette No 53 of 5 March 2010 - Supplemento Ordinario No 43.
} 
misura rilevante), ${ }^{73}$ this period cannot exceed two working days. ${ }^{74}$ Therefore, the right to vote at the general meeting is determined by reference to the shares registered on the record date in favour of the shareholder on the relevant intermediary's account. When the financial instruments are admitted for trading on the regulated market with the issuer's consent, the record date for holders of such instruments is the end of the seventh business day prior to the date of the general meeting (Article 2370(5) of the Italian Civil Code and Article 83-sexies(1)(2) of the Italian Securities Act). Pursuant to this new regime, shareholders may attend a meeting and exercise voting rights in respect of those shares even if they transfer their shares after the record date. ${ }^{75}$

In accordance with the solutions adopted by the Member States, trading shares in the period between the record and voting date is possible and allowed. This, in turn, enables empty voting with all its adverse consequences. Some legislators intended to limit empty voting by prescribing a shorter period between the record and voting date (two working days in the UK, Ireland and Cyprus). However, proxies who seek instructions on how to vote usually set the date for receiving instructions on the cut-off date. Therefore, the less time gap there is for trading, the shorter is the time to receive instructions. Portugal has an interesting approach here. It requires the person who declares that it will attend the general meeting but has transferred its shares to another person in the period between the record and voting date to duly inform the company general meeting and the National Securities Market Commission (Commisão de Mercado de Valores Mobiliários - CMVM). ${ }^{76}$

On April 2014 the European Commission published a proposal for the revision of the Shareholder Rights Directive (hereinafter: Proposal

\footnotetext{
73 Legislative Decree No 6 of 17 January 2003, published in Official Gazette No 17 of 22 January 2003 within 'società che fanno ricorso al mercato del capitale di rischio' differentiates two types of company: 'società con azioni quotate in mercati regolamentati' and companies whose shares are 'diffuse tra il pubblico in misura rilevante'. See more in $\mathrm{N}$ Ciocca, 'Individuazione delle società con azioni diffuse tra il pubblico in misura rilevante' in A Gambino, Società di capitali - Casi e materiali (G Giappichelli Editore 2006) 7.

74 F Pernazza, Corporations and Partnerships in Italy (2 ${ }^{\text {nd }}$ edn, Kluwer Law International 2012) 102. G Bonfante and others, Codice commentato delle societa' ( $3^{\text {rd }}$ edn, Ipsoa 2011) 673 highlight the discrepancy in court rulings in cases where the prescribed conditions had not been met. Some courts had seen the decisions voidable, whereas others held the general meeting decisions null and void.

75 N Abriani and others, Diritto delle società (Manuale breve) ( $5^{\text {th }}$ edn, Giuffrè Editore 2012) 195; S Di Amato, G Muscolo and G Sciumbata, Le assemblee nelle S.p.A. (Giuffrè Editore 2011) 81; A Ferrucci and C Ferrentino, Società di capitali, società cooperative e mutue assicuratrici, Tomo I ( ${ }^{\text {nd }}$ edn, Giuffrè Editore 2012) 577; Luca (n 44) 327-331.

76 AEM - Associação de Empresas Emitentes de Valores Cotados em Mercado, 'Esma's Call for Evidence on Empty Voting' (November 2011) <http://www.emitentes.pt/images/media/docs/170_logos_526111125_AEM_EmptyVoting_RespostaConsultaPu\%C5\%93blica_ enviada.pdf $>$ accessed 1 April 2015; European Securities and Markets Authority (ESMA), 'Feedback Statement Call for Evidence on Empty Voting', available at <http://www.esma. europa.eu/system/files/2012-415.pdf> accessed 1 April 2015.
} 
SRD). ${ }^{77}$ According to the new rules, intermediaries holding shares on behalf of shareholders would be required to disclose the contract details with shareholders to companies if they so requested. Such shareholder identification would allow listed companies to communicate directly with the shareholders and enable their proactive engagement. Shareholders might enter into discussion with the board on relevant corporate governance issues.

Although the Proposal SRD does not preclude the occurrence of empty voting, it insists on the disclosure of contract details between the holder of the voting rights and its contracting party, which enables other shareholders to become aware of the short position of the particular voter. Since the basic idea of the proposed revision is not to forbid but to inform other shareholders about indirect holding arrangements, for a complete assessment of the disclosure duties one should take into account the provisions of the Transparency Directive, being the 'master' directive for the disclosure of certain blocks of voting rights.

\section{Empty voting and the (revised) Transparency Directive}

It is widely known that the acquisition or alienation of certain blocks of voting rights in a listed company triggers the duty of the respective company to disclose this information to the public. Transactions involving a block of shares and pertaining voting rights give an important market signal and therefore could cause the rise or fall of the share price. In order to evade the disclosure of the acquisition of voting rights, an investor may resort to the indirect acquisitions of voting rights. The investor might be motivated to evade disclosure especially if he/she intends to take over the listed company and wants the takeover bid to come as a surprise when he/she acquires the controlling block. If the market recognises the investor's appetite for a takeover, the price of the share would probably rise. The reason lies in the fact that once his/her takeover bid is launched, the bidder should not offer less than the market price of the share. The situation is described as shareholders gaining their 'takeover premium'. ${ }^{78}$ By holding his/her voting portfolio through various forms

\footnotetext{
77 The proposal has been prepared following three extensive public consultations (Commission (EC) 'Corporate governance in financial institutions' (Green Paper) COM (2010) 284 final, 2 June 2010; Commission (EC) 2011 'The EU corporate governance framework' (Green Paper) COM (2011) 164 final, 5 April 2011; Commission (EC) 'Long-term financing of the EU economy' (Green Paper) COM (2013) 150 final, 25 March 2013) and has taken into account the views expressed by stakeholders. The text of the proposal is available at <http: / / eur-lex.europa.eu/legal-content/EN/TXT / ?qid=1398680488759\&uri=COM:2014: 213:FIN> accessed 30 October 2014.

78 BE Eckbo, 'Bidding Strategies and Takeover Premiums: A Review' (2009) 15 Journal of Corporate Finance 149-178, also available at <http://ssrn.com/abstract=1198342> accessed 13 April 2015.
} 
of indirect holdings, including derivatives, the intended bidder might go under the radar until he/she reaches the controlling stake. ${ }^{79}$ This is why the EU legislator has introduced special rules on the calculation of voting rights whose aim is to add certain indirect holdings to the investor's direct holdings in order to force the shareholder to disclose the whole block. ${ }^{80}$

In order to improve legal certainty and effectiveness, a revision of the provisions of the Transparency Directive of 2004 has been initiated. ${ }^{81}$ The revised Transparency Directive entered into force on 26 November 2013. Member States are required to adopt the necessary measures to transpose it into national law within two years (by 26 November 2015). ${ }^{82}$

The disclosure rules have been extended both to include direct or indirect holdings of financial instruments with an economic effect similar to the holdings of shares, whether or not they confer a right to a physical

79 DA Zetzsche, 'Continental AG vs Schaeffler, Hidden Ownership and European Law: Matter of Law or Enforcement?' (2009) 10 European Business Organization Law Review <http:/ /ssrn.com/abstract=1170987>_accessed 13 April 2015.

80 Directive 2004/109/EC of the European Parliament and of the Council of 15 December 2005 on the harmonisation of transparency requirements in relation to information about issuers whose securities are admitted to trading on a regulated market and amending Directive 2001/34/EC [2004] OJ L390/38. See also Commission (EC) 'Report from the Commission to the Council, the European Parliament, the European Economic and Social Committee and the Committee of the Regions, Operation of Directive 2004/109/EC on the harmonisation of transparency requirements in relation to information about issuers whose securities are admitted to trading on a regulated market' COM (2010) 243 final, 27 May 2010 <http://ec.europa.eu/internal_market/securities/docs/transparency/directive/com-2010-243_en.pdf> accessed 10 July 2014. See also Commission (EC) (n 35); Committee of European Securities Regulators, 'CESR proposal to extend major shareholding notifications to instruments of similar economic effect to holding shares and entitlements to acquire shares' (Consultation Paper) January 2010 <http:/ /www.esma.europa.eu/system/ files/09_1215b.pdf $>$ accessed 1 September 2014. The Transparency Directive Assessment Report highlighted two ways that the empty voting issue could be managed: one is to enhance disclosure duties and the other is to ban empty voting. Mazars, 'Transparency Directive Assessment Report' (2009) <http:/ / ec.europa.eu/internal_market/securities/docs/ transparency/report-application_en.pdf $\geq$ accessed 5 October 2014.

81 On 25 October 2011, the European Commission proposed amendments to the Transparency Directive of 2004. Commission (EC), 'Proposal for a Directive of the European Parliament and of the Council amending Directive 2004/109/EC on the harmonisation of transparency requirements in relation to information about issuers whose securities are admitted to trading on a regulated market' COM (2011) 683 final, 25 October 2011 <http:// eur-lex.europa.eu/LexUriServ/LexUriServ.do?uri=COM:2011:0683:FIN:EN:PDF> accessed 26 July 2014.

82 Directive 2013/50/EU of the European Parliament and of the Council of 22 October 2013 amending Directive 2004/109/EC of the European Parliament and of the Council on the harmonization of transparency requirements in relation to information about issuers whose securities are admitted to trading on a regulated market, Directive 2003/71/EC of the European Parliament and of the Council on the prospectus to be published when securities are offered to the public or admitted to trading and Commission Directive 2007/14/ EC laying down detailed rules for the implementation of certain provisions of Directive 2004/109/EC [2013] OJ L294/13, Art 4. 
settlement. The new definition focuses on the economic effect of the applied financial instrument rather than enumerating the types of financial instruments covered. This catch-all provision will cover all derivatives, financial instruments and contracts. ${ }^{83}$

According to the revised Transparency Directive, the holder must calculate and notify all financial instruments relating to the same issuer. However, to avoid any confusion as to the nature of the holdings, the holder of shares and financial instruments should in the notification separately disclose the amount of holdings of shares and the amount of holdings of financial instruments, respectively. The newly adopted solution enables the investor community to comprehend with a greater amount of probability the position of the shareholder: is the one who is holding positions in financial derivatives a long or short investor and how will this influence his/her voting. In a similar vein, the revised Transparency Directive also leads to greater harmonisation of the calculation rules. ${ }^{84}$

As far as empty voters are concerned, it is worth emphasising that only long positions are to be taken into account for the calculation of voting rights. Also, in accordance with the adopted rules, long positions cannot be netted off against short positions relating to the same underlying issuer. ${ }^{85}$ Article 13.a(2) of the Transparency Directive requires the voting rights that have already been notified to be notified again when the natural person or the legal entity has acquired the underlying shares

\footnotetext{
83 In accordance with the adopted rules, financial instruments cover options, transferable securities, futures, swaps, forward rate agreements, contracts for differences and any other contracts or agreements with similar economic effects which may be settled physically or in cash if they satisfy any of the conditions set out in Art 13(1)(a) and (b) of the Transparency Directive. In addition, the European Securities and Markets Authority (ESMA) is obliged to establish an indicative list of financial instruments that are subject to notification requirements taking into account technical developments on financial markets. For more about ESMA's position, see L Degabriel, 'ESMA's Role in the Supervision of Transparency Requirements' (2014) 5 Zeitschrift für Internationale Rechnungslegung 193-195.

84 The implementation of Art 13 of the Transparency Directive of 2004 differs in the EU Member States. One group of states (Austria, Bulgaria, Cyprus, Spain, Luxembourg, Italy, and Poland) are of the view that disclosure pertaining to Art 13 should be viewed separately from disclosure duties arising under Art 9. The second group of states (Belgium, Germany, Denmark, Estonia, Greece, Finland, France, Hungary, Ireland, Lithuania, Malta, Netherlands, Portugal, Sweden, Slovenia, Slovakia, Great Britain, Norway and Ireland) has obliged investors to add voting rights from shares to the voting rights from other financial instruments in order to verify whether the threshold prescribed in Art 9 of the Directive has been exceeded. CESR, ESMA's predecessor, held in 2005 that coupling those blocks is not necessary. See the Committee of European Securities Regulators, 'CESR's Final Technical Advice on Possible Implementing Measures of the Transparency Directive' (June 2005) <http:// ec.europa.eu/internal_market/securities/docs/prospectus/cesr-05-407_en.pdf> accessed 10 March 2015. The newly adopted regulation introduces stricter demands.

85 Directive 2004/109/EC of the European Parliament and of the Council of 15 December 2005 on the harmonisation of transparency requirements in relation to information about issuers whose securities are admitted to trading on a regulated market and amending Directive 2001/34/EC [2004] OJ L390/38, Art 13 (1b).
} 
and such acquisitions result in the total number of voting rights reaching or exceeding the threshold laid down by Article 9(1) of the Transparency Directive.

Although the motivation for the proposed modifications was investor protection, the additional costs related to the disclosure of information may not be welcomed by market participants and may in turn trigger the lowering of the value of shares. ${ }^{86}$

Article 10 of the Transparency Directive is relevant for empty voting through the practices of lending or borrowing shares. The review of the operation of the Transparency Directive indicated that $55.9 \%$ of shareholders believe that the lending of voting rights should be made transparent, and the majority of shareholders (65.6\%) took the position that borrowed voting rights should be included in the calculation of the voting threshold that triggers the notification duties. ${ }^{87}$

However, the issue of borrowed shares in the revised Transparency Directive has not been addressed explicitly. So a question remains concerning what the ground provision is for imposing the duty to calculate borrowed shares, and who is obliged to disclose the transaction - the borrower or the lender?

The duty to aggregate borrowed shares stems from Article 10, while Article 9 calls for disclosure. Any natural person or legal entity, to the extent they are entitled to acquire, to dispose of or to exercise voting rights held by a third party under an agreement concluded with that person or entity providing for the temporary transfer for consideration of the voting rights in question, is under the duty to disclose. The provision is structured in a way that the person transferring his/her voting right (temporarily and for consideration) remains the holder of the securities. He/she has transferred his/her voting right only and for consideration. If voting rights are transferred without consideration, this rule is inapplicable. If the parties conclude a repurchase agreement, the person who purchased the shares does not exercise the voting right of the other person, but acquires their own voting right, which would be returned (sold back) on a date set in the contract. Since this is short-term share acquisition, the person might use the 'repo' shares to cast a vote against the company's

\footnotetext{
${ }^{86}$ Market research shows that an increase in the amount of information a company is obliged to disclose causes a decrease in its share value. For more on this issue, see DA Zetzsche, 'Against Mandatory Disclosure of Economic-Only Positions Referenced to Shares of European Issuers: Twenty Arguments Against the CESR Proposal' (2011) 11(2) European Business Organization Law Review <http://ssrn.com/abstract=1559787> accessed 27 July 2014; Barry, Hatfield and Kominers (n 9) 11; R Scalcione, The Derivatives Revolution: A Trapped Innovation and a Blueprint for Regulatory Reform (Kluwer Law International 2011) 274-275.

87 Commission (EC) (n 35) 80.
} 
interest, while, due to the sell back right / obligation, they would not bear any economic consequence of their vote. The investment risk and economic consequences of the vote cast by the temporary 'repo' shareholder would pertain to the shareholder who would buy back the shares in question.

According to the Transparency Directive Assessment Report, 88 a typical stock lending agreement results in a transfer of the shareholder's rights from the lender to the borrower. This is applicable both to the bearer and the registered shares. The working group took the position that borrowing shares transactions are covered by the transparency obligation as stipulated in Article 9 of the Transparency Directive.

The question concerning which contracting party is to disclose the acquisition - the lender and/or borrower - has divided the Member States. The Transparency Directive Assessment Report stated that, since Article 9 of the Directive is applicable, the transaction should be notified both by the lender and the borrower. By imposing a notification obligation on both contracting parties, the market would be provided with complete and consistent information about the concluded transaction. ${ }^{89}$ On the one hand, the lender would disclose his/her shift from full owner to holder of a right to re-acquire the shares, and, on the other hand, the borrower would declare his/her status as owner and his/her obligation to return the shares.

Article 10(b) of the Transparency Directive is applicable if the 'voting rights held by a third party are acquired under an agreement concluded with that person or entity'. While the form of the agreement is not prescribed, all forms are eligible (ie oral, written, etc). This raises the question whether this provision is meant to cover situations where an agreement does not provide for the transfer of voting rights but such transfer may be the logical consequence of the agreement. Moreover, Article 10(g) of the Transparency Directive states that the notification obligation applies to "voting rights held by a third party in its own name on behalf of that person or entity'. ${ }^{90}$

The provisions of the Transparency Directive have not been transposed with exactly the same content in all EU Member States. ${ }^{91}$ Relating to the issue of whether or not a loan agreement triggers the duty to

88 Mazars (n 80) 124.

89 Commission (EC) (n 35) 82.

90 The provision of Art 10(g) of the Transparency Directive is implemented in Croatian law by Art 417(1)(7) of the Croatian Capital Market Act which explicitly prescribes 'voting rights held by a third party in its own name on behalf of that person or entity'.

91 The issue is addressed by $\mathrm{H}$ Fleischer and U Schmolke, 'Die Reform der Transparenzrichtlinie: Mindest- oder Vollharmonisierung der kapitalmarktrechtlichen Beteiligungspublizität?' (2010) 32 Neue Zeitschrift für Gesellschaftsrecht 1241-1243. 
notify, the Member States have declared the affirmative. However, they have adopted various standpoints concerning which subject has the duty to notify.

In Croatia, Article 10(b) of the Transparency Directive was implemented in Article 417(1) of the Capital Market Act (hereinafter: CMA). The issue of who has the obligation to notify should be viewed in respect of the provision in Article 413 CMA. According to this provision, disclosure is compulsory for both the lender and the borrower. Each person to whom the obligation applies is individually required to notify the issuer and the Agency pursuant to Article $413 \mathrm{CMA}$, although the CMA allows a single common notification by both parties. Croatian law does not explicitly regulate disclosure of voting rights acquired under financial derivatives.

In Germany, the relevant provision is Article $21 \mathrm{ff}$ of the Securities Trading Act (WpHG). ${ }^{92}$ In the doctrine, different views have been expressed as to the question of which side has the obligation to notify. Prior to the last amendment, the common standpoint was that, pursuant to Article $22 \mathrm{WpHG}$, the lender was obliged to notify about the holdings of the shares transferred to the borrower. ${ }^{93}$ The view was expressed that the voting rights should be added to those of the borrower when the borrower was the one exercising voting rights. Led by both arguments, case law has adopted a standpoint where, for the purpose of notifying, pursuant to Article 22(1) WpHG, voting rights are attributed to the lender, but only in the case where the lender is able to influence the voting. In the very well-known case decided by the German Federal Supreme Court in $2009,{ }^{94}$ a major shareholder in a partnership company limited by shares reached the $95 \%$ threshold by entering into a lending agreement and

\footnotetext{
92 Wertpapierhandelsgesetz (WpHG) in der Fassung der Bekanntmachung, published on 9 September 1998, BGBl vol I, 2708, as last amended by Art 2 of the law of 1 April 2015, BGBl vol I, 434.

93 A Merkner and M Sustmann, 'Wertpapierleihe und Empty Voting - Weitergehender Transparenzbedarf im WpHG?' (2010) 30 Neue Zeitschrift für Gesellschaftsrecht 1171.

94 Bundesgerichtshof (German Supreme Court), judgment of 16 March 2009 (II ZR 302/06) BGHZ 180, 154.The plaintiffs were minority shareholders of the defendant (a partnership company limited by shares) Lindner Holding KGaA, whose founder and General Partner was JL. In 2004 he held approximately $1.19 \%$ of the shares of the defendant. Approximately $31.33 \%$ were held by JL GmbH (in which he was $100 \%$ owner and managing director). Approximately $62.59 \%$ of the shares were held by L Beteiligungs-GmbH whose members were the wife and daughters of JL. Through a securities lending agreement of 18 October 2004, JL and JL GmbH lent their shares to L Beteiligungs-GmbH (for an indefinite period of time) (the first time) terminating on 30 June 2007. By a letter dated 19 October 2004, L Bet.-GmbH showed the defendant that his stake had grown to more than $95 \%$ in the share capital and demanded the initiation of the squeeze-out procedure according to Art 327a et seq AktG. An Extraordinary General Meeting of the defendant was called on 25 February 2005, and the squeeze-out decision was rendered by granting cash compensation to minority shareholders of $€ 28.52$ per share. BGH held that the request of the defendants was founded. BGH was of the opinion that securities lending does not give the borrower 'share ownership of a second class' but full ownership of the 'borrowed' shares.
} 
afterwards initiated a squeeze out of minority shareholders. Although lower instance courts found this practice abusive, the German Federal Supreme Court ruled that the borrower, by virtue of the lending agreement, had acquired full (although temporary) ownership of the borrowed shares, which could not be understood as abusive, so the court ultimately upheld the squeeze-out procedure. The German legislator sought to tackle the issue of empty voting through borrowing or lending shares by changing Article $25 \mathrm{WpHG}$. In the new Article 25.a WpHG that entered into force on 1 February 2012, ${ }^{95}$ disclosure duties are now extended to include 'other instruments ("sonstige Instrumente") which make it possible' to acquire voting shares. Under the new rule, the existence of the right to demand the return of the lent / borrowed shares should be disclosed notwithstanding the lender's eligibility to exercise his voting rights. ${ }^{96}$ According to the existing provisions, the obligation to notify is imposed both on the lender and the borrower.

As for equity swaps, similar instruments that enable empty voting, the issue is also covered by the newly adopted Article 25.a WpHG (Mitteilungspflichten beim Halten von weiteren Finanzinstrumenten und sonstigen Instrumenten) that entered into force on 1 February 2012.97 While Article 25.a WpHG significantly extends the notification obligations to all financial instruments and other instruments ('sonstigen Instrumenten') which (directly or indirectly) enable (ermöglichen) the holder or third parties to acquire ordinary (voting) shares of the German issuers, equity swaps are also covered. It is irrelevant whether the equity swap is settled in cash or in equity. Apart from (equity) swaps, Article 25.a WpHG covers in particular the financial contracts for difference, cash-settled call options, put options and other transactions that have the economic consequence of allowing for the acquisition of voting rights. ${ }^{98}$ In the view

\footnotetext{
95 See the Act on Enhancement of Investor Protection and Improved Functioning of the Capital Market (Gesetz zur Stärkung des Anlegerschutzes und Verbesserung der Funktionsfähigkeit des Kapitalmarkts (Anlegerschutz- und Funktionsverbesserungsgesetz (AnsFuG)), published on 5 April 2011, BGBl vol I, 538, which amended the Securities Trading Act (Wertpapierhandelsgesetz (WpHG) in der Fassung der Bekanntmachung), published on 9 September 1998, BGBl vol I, 2708, as last amended by Art 2 of the Law of 1 April 2015, BGBl vol I, 434.

96 A Merkner and M Sustmann, "Erste "Guidance" der BaFin zu den neuen Meldepflichten nach §§ 25, 25a WpHG' (2012) 7 Neue Zeitschrift für Gesellschaftsrecht 244; Mittermeyer (n 24) 115 .

97 See the Act on Enhancement of Investor Protection and Improved Functioning of the Capital Market (Gesetz zur Stärkung des Anlegerschutzes und Verbesserung der Funktionsfähigkeit des Kapitalmarkts (Anlegerschutz- und Funktionsverbesserungsgesetz (AnsFuG)), published on 5 April 2011, BGBl vol I, 538, which amended the Securities Trading Act (Wertpapierhandelsgesetz (WpHG) in der Fassung der Bekanntmachung), published on 9 September 1998, BGBl vol I, 2708, as last amended by Art 2 of the law of 1 April 2015, BGBl vol I, 434.

98 Fleischer and Schmolke (n 10) 849; H Krause, “Stakebuilding” im Kapitalmarkt-und Übernahmerecht' in JA Kämmerer and R Veil, Übernahme- und Kapitalmarktrecht in der Reformdiskussion (Mohr Siebeck 2013) 169.
} 
of the German Federal Financial Supervisory Authority (BaFin), there is high likelihood that Article 25.a WpHG will include shareholders' agreements containing the pre-emption clause (Vorkaufsrechte), as well as put options - the right to sell shares (Andienungsrechte). It should be noted that, according to German law, the notification threshold is set at 3\% of the total voting rights. However, in the case that voting rights might be acquired by holding financial instruments, the threshold has been raised to $5 \%$.

In France the interpretation of the laws has led to the conclusion that lenders have the obligatory duty to notify. However, during the course of the implementation of the Transparency Directive different views prevailed resulting in the adoption of the opposing view under which the borrower is obliged to notify. ${ }^{99}$ In order to combat excessive empty voting through borrowing shares, a new disclosure requirement has been introduced in the revised Article L 225-126 of the French Commercial Code. ${ }^{100}$ Accordingly, if a person holds by virtue of a temporary assignment or any transaction giving him/her the right or obligation to resell or return the respective shares to the assignor and those shares represent more than $0.5 \%$ of the voting rights, a person is required to inform the company and the AMF of the total number of shares that he/she temporarily holds. The disclosure must be made no later than three business days prior to the general meeting, provided that the lending agreement is still in force on the day of the general meeting. Finally, the issuer has to publish the information. It has to be emphasised that the new regime provides drastic sanctions. If the borrower does not comply with the disclosure obligation, the shares will lose their voting entitlement at the general meeting. In addition, a court can separately prohibit the exercise of the voting right of a non-complying shareholder for up to five years. Finally, a shareholder resolution which involves a non-complying shareholder can be challenged in court and declared invalid.

As per equity swaps, new rules entered into force on 1 October 2012. ${ }^{101}$ In calculating disclosure thresholds, all voting rights attached to the shares already issued are taken into account: CSDs granting to the reporting person an economic effect similar to that of owning the shares,

\footnotetext{
99 Autorité des Merchés Financiers (AMF) 'Report of the working group chaired by Yves Mansion on securities lending before general meetings of shareholders' (January 2008) <http: / /www.amf-france.org/en_US/Publications / Rapports-des-groupes-de-travail/Archives.html?docId=workspace\%3A\%2F\%2FSpacesStore\%2Fbc80320c-1a92-4041-b6d707a5c95caa88> accessed 20 April 2015; Mazars (n 80) 124. See Arts L233-7 and L233-9 of the French Commercial Code and Arts 223-11 and 223-17 of the AMF General Regulations. ${ }^{100}$ Loi No 2010-1249 du 22 octobre 2010 de régulation bancaire et financière [2010] JORF 18984.

${ }^{101}$ Loi No 2012-387 du 22 mars 2012 relative à la simplification du droit et à l'allégement des démarches administratives [2012] JORF 5226.
} 
agreements or other financial instruments which have the same economic (financial) effect as holdings of shares, ie equity swaps, contract-for difference, cash-settled call options. ${ }^{102}$

In the UK, Article 10 of the Transparency Directive was transposed through the Disclosure and Transparency Rules - Chapter 5 (DTR 5.2). ${ }^{103}$ Accordingly, the duty to notify lies with the borrower. The adopted solution has its ratio in the fact that it is the lender who is the one who controls the right to call back the shares. Although the shareholder alienates the shares, he/she simultaneously acquires the right to claim them back. Since the share would return on the lender's initiative, the borrower may not freely dispose of them, which induces his/her obligation to notify about the lending transaction. ${ }^{104}$ The disclosure of derivatives in the UK is provided in Rules 8.3 and 9.1 of the Takeover Code and they are applied in the takeover procedure and in the provisions of Chapter 5 of the DTR. In 2005, the Takeover Panel amended the Takeover Code to require disclosure of cash-settled derivative (Contract for Difference, CfD) positions at $1 \%$ or more in both the target and the bidding company during the offer period. Disclosures of major shareholder notification under the FSA Handbook (DTR 5) were amended in 2009 in a way that this obligation applies independently of whether these instruments are settled

102 Before the amendments and modifications of the French Commercial Code that came into force on 1 October 2012, the issue of equity-settled derivatives and cash-settled derivatives had been addressed in a different manner. For instance, shares or voting rights that may have been acquired by means of equity-settled derivatives were required to be taken into account when calculating the shareholders' voting power under the condition the shares had already been issued and in the case that the holder of the financial instruments may acquire voting rights based on the holder's own discretionary assessment in accordance with the arrangement or financial instrument, at any time, irrespective of its maturity (Art L 233-9(I)(4) of the French Commercial Code). In contrast, cash-settled financial instruments were not taken into account when calculating the shareholders voting power for the purpose of informing on changes in the percentage of voting rights. See Ordonnance No 2009-105 du 30 janvier 2009 relative aux rachats d'actions, aux déclarations de franchissement de seuils et aux déclarations d'intentions [2009] JORF 26 sur 182. Shareholders required to disclose the holding of voting rights in a listed company were also required to disclose the number of shares which are the basis for issuing/concluding 'an agreement or cash-settled financial instrument which ensures its holder the same financial interest as holding shares', as well as the number of voting rights attached to the shares. However, the holding of voting rights which may be acquired through holding cash-settled financial instruments was not taken into account when calculating the shareholders' voting power. See Art L 233-7 of the French Commercial Code. Nonetheless, French jurisprudence started seeing those derivatives as a part of disclosure duties. See the ruling in the case Wendel/ Saint Gobain as well as the ruling in Hermes/LVMH, available at $<$ http://ec.europa.eu/ commission_2010-2014/piebalgs/multimedia/pdf/20111026_memo-11-734_en.pdf> accessed 15 April 2015.

${ }^{103}$ FSA Handbook, Disclosure and Transparency Rules - Chapter 5 (DTR 5). See more in A Hudson, Securities Law (Sweet \& Maxwell 2008) 405-406.

${ }^{104}$ Mazars, Transparency Directive Assessment Report, Executive summary and possible improvements' (2009) 13 <http://ec.europa.eu/internal_market/securities/docs/transparency/report-application_summary_en.pdf> accessed 20 November 2014. 
physically or in cash. The FSA opted for the general disclosure obligation triggered by CfD positions at or exceeding 3\%. ${ }^{105}$ Vote holders must notify a listed company of the level of voting rights within two trading days of the date upon which they acquired or disposed of the CfD that triggered the notification obligation. ${ }^{106}$ If the FSA discovers that an issuer of securities admitted to trading on a regulated market has failed to comply with the transparency rules, it may publicly censure the issuer and/or suspend or prohibit trading in the issuer's securities.

In Italy, Resolution No 16850 of 1 April 2009 of the market regulator, CONSOB, which entered into force on 24 April 2009, implemented the Transparency Directive. Accordingly, disclosure duty lies with the lender. ${ }^{107}$ Article 118(2) of CONSOB Regulation No 11971 provides that, when the shares are subject to security lending or contango ${ }^{108}$ transactions, the disclosure obligation is both the lender's or the contango payer's and the borrower's or the contango broker's. This obligation does not encumber the borrower or the contango broker in the case envisaged by Article 119bis(3.a), provided that the same does not exercise a voting right. As for equity swaps and other derivatives suitable for empty voting, on 9 September 2011 CONSOB approved new rules on the transparency of major holdings in listed issuers which came into force on 9 October 2011. ${ }^{109}$ By modifying CONSOB Regulation No 11971 of 14 May 1999 implementing Legislative Decree No 58 of 24 February 1998 Consolidated Law on Finance ('Testo Unico'), the law extended the disclosure regime to equity swaps and other financial instruments and contracts granting a long position over the underlying shares. In order to streamline the reporting regime, the newly adopted rules increase the first relevant threshold for the disclosure of long potential holdings from the current $2 \%$ to $5 \%$ of the relevant issuer's voting capital. ${ }^{110}$

\footnotetext{
${ }^{105}$ M Kettunen and WG Ringe, 'Disclosure Regulation of Cash-Settled Equity Derivatives: An Intentions-Based Approach' (2011) Oxford Legal Studies Research Paper No $36<\mathrm{http}$ :// ssrn.com/abstract=1844886> accessed 10 July 2014, highlight: 'Instead of a general disclosure obligation, CfD disclosure should be narrowed to situations where these instruments are to be used to obtain or increase control in the target company, either through a takeover or by otherwise influencing shareholder decision-making.'

${ }^{106}$ The issuer must then make that information public as soon as possible. See more in M Blair, G Walker and S Willey (eds), Financial Markets and Exchanges Law $\left(2^{\text {nd }}\right.$ edn, OUP 2012) 200.

${ }_{107}$ Mazars (n 104) 13.

${ }^{108}$ A situation where the futures price of a commodity is above the expected future spot price.

${ }^{109}$ Resolution No 17919 of 9 September 2011, published in Official Gazette No 220 of 21 September 2011 and in CONSOB fortnightly bulletin no 9.1, September 2011.

110 This increase is based on the cost benefit analysis carried out during the consultation process which indicated that the benefits in terms of market efficiency and transparency arising from the first disclosure threshold had proved to be rather marginal compared to the associated compliance costs.
} 


\section{Facit}

The best way to limit the negative effects of empty voting is transparency and disclosure, the course taken by the EU legislator. The revised Transparency Directive has enhanced the sanctioning powers of the competent authorities of the Member States, instructing them to publish sanctions, except in certain circumstances as defined in Article 28b of the Transparency Directive. Competent authorities of the Member States are authorised to suspend the exercise of voting rights of an issuer who breaches the notification rules on major holdings. In some countries a shareholder not complying with his/her disclosure duties is exposed to even more drastic sanctions such as the suspension of his/her voting rights (by a court decision) for up to several years. ${ }^{111}$ The introduction of the disclosure regime is accompanied by additional costs, especially if both parties to the transaction should disclose, if the disclosure is continuous, and if the threshold is set low. Although disclosing both short and long positions before the general meeting is certainly the most important momentum, because it enables other shareholders to render an informed decision, there are reasons which support a continuous disclosure obligation over the entire business year. ${ }^{112}$ However, when prescribing disclosure duties, it is important to prevent information overload and to keep in mind that the mandatory disclosure of transactions leading to empty voting will not per se prevent its occurrence. In respect of the disclosure threshold, the current authors hold the view that the duty to disclose should be mandatory for existing shareholders who hold only a sizable long position, along with equally significant short positions. Only the magnitude of short positions (of otherwise long investors) shows a reduction/elimination of the investment risk that could be relevant to other shareholders. A separate disclosure of short and long positions is important, as is the disclosure of financial instruments which confer a right to a physical settlement distinct from those which confer the right to a cash settlement, as provided by the Transparency Directive.

Some positive effects of empty voting should not be disregarded. When other shareholders are aware of the existence of empty voters, they can react by resorting to minority shareholders rights. Their ultimate measure is to sell their shares. Therefore, empty voting could strengthen shareholder activism and their active participation in the company decision-making process and, in turn, contribute to stronger control of the company management. This would motivate the rest of the investors to actively exercise their rights attached to the shares. It should be stressed that certain empty voting methods such as share lending have positive

\footnotetext{
111 Ringe (n 4) 47.

112 Ringe (n 4) 53.
} 
effects and serve other functions in the capital market, especially the liquidity of shares.

The authors are of the opinion that empty voting would generally be attractive as long as it can be done under the radar. If disclosed, it could result in institutional investors losing their reputation, so their financial ingenuity would invent new methods to reach the desired result. Therefore, pure disclosure without 'teeth' is not enough, and it should be accompanied by powers of the competent body to sanction non-disclosure adequately.

When the disputes come to the court, the outcome of the battle is uncertain. Both the Lindner and Telus cases show diverging views of the first-instance court and the Supreme Court. In the Telus case, two differing court decisions were even accompanied by two different pieces of expert advice provided by two professors who have written extensively on empty voting (Henry Hu and Bernard Black). In such an unpredictable court environment where courts may resort to a formal or functional approach, the market regulator should be given the power to impose voting restrictions on particular shareholders. In this respect, the revised Transparency Directive seems to be on the right track, since it provides enforcement mechanisms for non-disclosure. 